\title{
SISTEM INFORMASI REKAM MEDIS PADA DINAS KESEHATAN KABUPATEN MUSIRAWAS BERBASIS WEB MOBILE
}

\author{
Taufik Rahman ${ }^{1}$, Lukman Hakim², Okta Maya Sari ${ }^{3}$ \\ ${ }^{1,3}$ Program Studi Informatika, Universitas Bina Insan, Lubuklinggau \\ ${ }^{2}$ Program Studi Rekayasa Sistem Komputer, Universitas Bina Insan, Lubuklinggau \\ e-mail: taufikrahman@univbinainsan.ac.id
}

\begin{abstract}
Abstrak
Rekam Medis adalah berkas yang berisikan tentang catatan identitas pasien dari pemeriksaan, pengobatan, dan tindakan lainnya yang berikan oleh dokter. Puskesmas di Kabupaten Musirawas tidak hanya 1 (satu), sehingga membuat pasien terdaftar di beberapa Puskesmas di Kabupaten Musirawas dan memiliki beberapa rekam medis yang terpisah yang dapat mengakibatkan penanganan medis yang salah atau tidak tepat sehingga bisa merugikan pasien. Di Puskesmas Kabupaten Musirawas dokumen atau data rekam medis harus disimpan di Puskesmas tempat pasien mendapatkan layanan rekam medis, sehingga mengakibatkan pasien tidak leluasa dalam membaca dan mendapatkan informasi kesehatan kecuali datang sendiri ke Puskesmas tersebut. Untuk mengatasi permasalahan yang ada peneliti melakukan penelitian sistem informasi rekam medis dengan berbasis web mobile. Dalam sistem ini, peneliti merancang sistem rekam medis pasien yang bisa langsung tersinkron untuk ke beberapa Puskesmas yang ada di Kabupaten Musirawas, metode penelitian yang digunakan dalam penelitian ini adalah metode pengembangan sistem dengan metode Waterfall, metode ini menyiratkan pendekatan yang sistematis dan berurutan pada perangkat lunak yang dimulai dari perencanaan (planning), pemodelan (modeling), konstruksi (construction), serta penyerahan perangkat lunak kepada pelanggan (deployment). Hasil penelitian yang didapatkan adalah dengan adanya sistem informasi rekam medis ini dapat memudahkan masyarakat dalam melakukan pendaftaran secara online, melakukan pemeriksaan secara mudah dan cepat, serta dapat melihat catatan medis kapan pun dan dimana saja tanpa perlu datang ke puskesmas.
\end{abstract}

Kata Kunci : Sistem Informasi; Rekam Medis; Puskesmas; Web Mobile

\begin{abstract}
Medical Records are files that contain patient identity records from examinations, treatments, and other actions given by doctors. Puskesmas in Musirawas District is not only 1 (one), thus making the patient registered at several Puskesmas in Musirawas Regency and having several separate medical records which could result in wrong or inappropriate medical treatment that could harm the patient. At the Musirawas District Health Center, medical record data or documents must be stored at the Puskesmas where patients receive medical record services, this results in patients not being free to read and get health information unless they come to the Puskesmas in person. To overcome the existing problems, researchers conducted research on mobile web-based medical record information systems. In this system, researchers designed a patient medical record system that can be synchronized directly to several Puskesmas in Musirawas Regency, the research method used in this study is a system development method with the Waterfall method, this method implies a systematic and sequential approach to software starting from planning, modeling, construction, and delivery of the software to customers (deployment). The results obtained are that the existence of this medical record information system can make it easier for people to register online, carry out easy and fast examinations, and can view medical records anytime and anywhere without the need to come to the puskesmas
\end{abstract}

Keywords : Information Systems; Medical records; Public health center; Web Mobile 


\section{PENDAHULUAN}

Perkembangan teknologi informasi sangat mempengaruhi berbagai segi kehidupan dan profesi. Salah satunya pada bidang pelayanan Kesehatan. Di setiap tempat layanan kesehatan pasti ada pasien yang akan datang untuk berobat maka akan dicatat baik identitas pasien, hasil diagnosa penyakit oleh dokter, obat yang diberika kepada pasien yang biasa disebut dengan Rekam Medis.

Rekam Medis adalah berkas yang berisikan tentang catatan identitas pasien dari pemeriksaan, pengobatan, dan tindakan lainnya yang berikan oleh dokter. Kelengkapan data rekam medis juga memberikan dokumentasi yang baik dan kecepatan dalam memberikan informasi. Penanganan yang salah atau terlambatnya dalam memberikan pelayanan medis kepada pasien dapat memberikan efek tidak baik untuk pasien, dan di Indonesia sendiri rekam medis di simpan di rumah sakit, puskesmas ataupun klinik tempat pasien mendapatkan layanan rekam medis.

Puskesmas di Kabupaten Musirawas adalah puskesmas yang selalu berusaha dalam memberikan pelayanan terbaik bagi pasiennya. Puskesmas di Kabupaten Musirawas tidak hanya 1 (satu), sehingga membuat pasien terdaftar di beberapa Puskesmas di Kabupaten Musirawas dan memiliki beberapa rekam medis yang terpisah yang dapat mengakibatkan penanganan medis yang salah atau tidak tepat sehingga bisa merugikan pasien. Di Puskesmas Kabupaten Musirawas dokumen atau data rekam medis harus disimpan di Puskesmas tempat pasien mendapatkan layanan rekam medis, sehingga mengakibatkan pasien tidak leluasa dalam membaca dan mendapatkan informasi kesehatan kecuali datang sendiri ke Puskesmas tersebut.

Untuk mengatasi permasalahan yang ada, peneliti mereview jurnal dengan judul
Sistem Informasi Rekam Medis Puskesmas Kecamatan Matram Jakarta yang membahas tentang penanganan besarnya tempat penyimpanan data pasien dan proses pencarian data, sehingga terbentuknya sebuah sistem yang bisa mempermudah dalam membantu petugas medis, bahkan dapat menghemat tempat penyimpanan data rekam medis pasien[1].

Sebuah penelitian yang berjudul tentang Perancangan Sistem Informasi Pelayanan Rekam medis di Puskesmas Arcamanik Kota Bandung membahas tentang mengurangi terjadinya duplikat data dengan penyimpanan data yang lebih aman dan untuk mempermudahkan dalam mendapatkan laporan dengan dukungan teknologi sistem informasi[2].

Penelitian yang berjudul Sistem Pengolahan Data Rekam Medis Berbasis Web Pada Puskesmas Perawatan Jambula Kota Ternate yang membahas tentang merancang sistem pengolahan data Rekam Medis pada Puskesmas Jambula Ternate yang memudahkan pada petugas medis [3].

Atas dasar penelitian sebelumnya, peneliti melakukan penelitian sistem informasi rekam medis dengan berbasis web mobile. Dalam sistem ini, peneliti merancang sistem rekam medis pasien yang bisa langsung tersinkron untuk ke beberapa Puskesmas yang ada di Kabupaten Musirawas, sehingga pasien hanya perlu melakukan sekali pendaftaran yang dilakukan secara online sehingga pihak Puskesmas lainnya bisa langsung melihat dan memberikan pelayanan tanpa harus mendaftarkan diri pasien dengan buku yang biasanya dilakukan. 


\section{TINJAUAN PUSTAKA}

\subsection{Sistem}

Sistem merupakan gabungan dari beberapa prosedur atau komponen yang digunakan untuk membuat pola yang terpadu atau terkait dari beberapa elemen yang bekerja sama untuk mencapai suatu target[4].

Sistem adalah sekelompok elemen yang sudah terintegrasi dengan tujuan yang sama untuk mencapai suatu tujuan. Terdiri dari beberapa sumber daya manusia, material, mesin, uang, dan informasi. Sumber daya tersebut berkelompok dengan bekerja sama untuk menuju tercapainya suatu tujuan tertentu yang ditentukan oleh pemilik atau manajemen tersebut[5].

Sistem adalah sekumpulan orangorang yang saling bekerja sama dengan aturan yang terstruktur dan sistematis untuk membentuk satu kesatuan dan saling berinteraksi dalam satu kesatuan serta bekerjasama untuk mencapai tujuan[6].

Berdasarkan definisi di atas, peneliti menyimpulkan bahwa sistem adalah kumpulan dari elemen-elemen dan gabungan dari prosedur-prosedur yang saling berhubungan atau berkaitan untuk menyelesaikan atau mencapai suatu tujuan.

\subsection{Informasi}

Informasi merupakan hal yang sangat penting dan berguna karena dengan adanya informasi tersebut kita dapat mengetahui kemajuan dan kegagalan proses sebuah pelaksanaan. Dan sistem yang kurang dengan adanya informasi dapat menunjukkan bahwa sistem tersebut sangat rapuh[5].

Informasi adalah data yang telah diorganisasi dan telah memiliki kegunaan dan manfaat[4].

Informasi adalah bentuk pengolahan data menjadi lebih hasil pengolahan data yang dapat memberikan sebuah arti yang berguna atau bermanfaat dalam meningkatkan

kepastian

bagi

penerimanya[6].

Berdasarkan definisi sebelumnya, dapat ditarik simpulan bahwa informasi merupakan kumpulan dari data-data yang telah diolah yang berguna serta mengandung makna bagi pemakainya.

\subsection{Sistem Informasi}

Sistem informasi merupakan suatu komponen yang saling berhubungan dan bekerjasama dalam mengumpulkan, memproses, menyimpan dan mendistribusikan sebuah informasi untuk mendukung pengambilan keputusan dalam suatu organisasi. Sistem informasi juga dapat membantu para manajer dan karyawan untuk meneliti permasalahan, memvisualisasikan pokok-pokok yang kompleks, dan menciptakan produk-produk yang baru[3].

Sistem Informasi merupakan sistem jaringan SPD (sistem pengolah data) yang sudah dilengkapi dengan kanal-kanal komunikasi yang sering digunakan dalam sebuah sistem organisasi data[7].

Sistem informasi merupakan suatu sistem organisasi dengan kebutuhan pengolahan transaksi harian yang selalu mendukung fungsi operasi dari organisasi yang bersifat manajer untuk dapat menyediakan laporan-laporan yang diperlukan oleh pihak luar dalam kegiatan strategi manajerial organisasi[8].

Berdasarkan definisi diatas dapat ditarik simpulan bahwa sistem informasi adalah komponen dari sekumpulan perangkat komputer yang saling berhubungan untuk mengumpulkan, memproses, menyimpan dan mendistribusikan data dalam bentuk informasi yang berguna untuk memecahkan masalah dan mendukung pengambilan keputusan. 


\subsection{Rekam Medis}

Menurut PERMENKES RI Nomer

269 Tahun 2008 Bab 1 Pasal 1 menyatakan bahwa berkas data yang berisikan penulisan dan dokumen yang meliputi identitas diri pasien, hasil periksa sampai selesai diberikan utuk pasien.

Menurut PERMENKES RI Nomer

269 Tahun 2008 Bab 2 Pasal 3 yang berisi[9]:

1. Identitas pasien

2. Tanggal dan waktu

3. Hasil anamesis, mencakup sekurangkurangnya keluhan dan riwayat penyakit.

4. Hasil pemeriksaan

5. Diaknisi

6. Rencana penatalaksana

7. Pengobatan atau tindakan

8. Pelayanan berikan kepada pasien

9. Persetujuan tindakan bila dijalankan.

Dalam peraturan menteri kesehatan

No. 269/2008, sistem rekam medis adalah berkas berisi catatan dan dokumen tentang pasien yang berisi identitas, pemeriksaan, pengobatan, tindakan medis lain pada sarana pelayanan kesehatan untuk rawat jalan, rawat inap baik dikelola pemerintah maupun swasta[10].

Menurut Peraturan Menteri

Kesehatan Nomor 55 tahun 2013, rekam medis merupakan sebuah berkas yang berisikan dokumen dan catatan mengenai identitas pribadi pasien, pemeriksaan, diagnosa, tindakan, dan pelayanan lainnya yang diberikan pada pasien pada fasilitas pelayanan kesehatan. Rekam medis bersifat rahasia dan dimiliki oleh pasien. Tujuan dari rekam medis yaitu sebagai penunjang tertib administrasi dalam upaya peningkatan pelayanan kesehatan di rumah sakit[11].

Berdasarkan definisi di atas, peneliti menyimpulkan bahwa rekam medis merupakan bukti tertulis tentang berkas data yang berisikan tentang catatan atau dokumen yang meliputi idnetitas diri pasien dari pemeriksaan, pengobatan, tindakan dan pelayanan lain yang telah diberikan kepada pasien atau hasil periksa sampai selesai sampai selesai dengan pelayan rekam medis yang lebih efisien, efektif dan dapat dipertanggungjawabkan.

\subsection{Puskesmas}

Puskesmas adalah suatu kesatuan organisasi fungsional yang berlaku sebagai pusat pengembangan kesehatan masyarakat, puskesmas dapat memberikan pelayanan rawat inap selain pelayanan rawat jalan. Hal ini disepakati oleh puskesmas dan dinas kesehatan yang bersangkutan. Puskesmas biasanya memiliki sub unit pelayanan seperti puskesmas pembantu, puskesmas keliling, posyandu, pos kesehatan desa maupun pos bersalin desa[3].

Puskesmas adalah Unit Pelaksana Teknis (UPT) dari Dinas Kesehatan Kabupaten/Kota yang bertugas untuk bertanggung jawab dalam menyelenggarakan pembangunan kesehatan pada suatu wilayah kerja[12].

Puskesmas merupakan penyelenggara pelayanan kesehatan yang paling dekat dengan masyarakat menunjukan lebih dari $40 \%$ penduduk Indonesia yang memanfaatkan pelayanan kesehatan di Puskesmas[8].

Berdasarkan definisi diatas bisa ditarik simpulan bahwa puskesmas merupakan sebuah organisasi yang memiliki multifungsi bagi pelayanan kesehatan masyarakat yang telah disepakati oleh Dinas Kesehatan Kabupaten/Kota. Dengan memiliki sub unit pelayanan puskesmas menjadi ujung tombak dalam menyelenggarakan pembangunan kesehatan pada suatu wilayah di Indonesia.

\subsection{Web Mobile}

Mobile yang memiliki arti bergerak atau berpindah-pindah tempat. Sehingga diperoleh definisi web mobile merupakan 
aplikasi yang bisa dijalankan dimana saja, bisa lewat android maupun laptop[13].

Web mobile adalah aplikasi yang dijalankan menggunakan browser, dengan bahasa pemrograman yang digunakan yaitu HTML, CSS, Javascript dan PHP. Website yang bisa menyesuaikan ukuran tampilan layout-nya mulai dari smartphone, tablet ataupun computer[14].

Berdasarkan definisi diatas, dapat ditarik simpulan bahwa web mobile merupakan sebuah aplikasi yang dijalankan menggunakan browser, dengan bahasa pemrograman dari HTML, CSS, Javascript dan $P H P$ bisa dijalankan dimana saja, bisa melalui android, tablet bahkan computer, karena mobile yang memiliki arti berpindahpindah maka tampilan website ini bisa menyesuaikan ukuran layout-nya.

\subsection{Penelitian Terdahulu}

Dalam penelitian ini, peneliti mengacu pada penelitin terdahulu yang relevan dengan penelitian yang akan dilaksanakan saat ini. Berikut ini beberapa hasil penelitian yang relevan yang dijadikan bahan telaah bagi peneliti.

Lydia Salvina Helling, dkk (2019) dengan judul Siremis : Sistem Informasi Rekam Medis Puskesmas Kecamatan Mataram, menyimpulkan bahwa sistem ini dapat menghemat tempat penyimpanan data pasien yang terdapat dalam rekam medis. Dan juga dapat membantu petugas-petugas yang bertugas di bagian loket, bagian poliklinik, dokter dan khusunya bagian rekam medis dalam melakukan pencarian data rekam medis[1].

Iwansyah Putra, dkk (2017) dengan judul Rancang Bangun Aplikasi Rekam Medis untuk Praktik Pribadi Dokter Berbasis
Android dan Memanfaatkan Layanan Web, menyimpulkan bahwa kebutuhan pengguna untuk mengelola data rekam medis telah diperoleh melalui wawancara, aplikasi mobile yang dikembangkan hanya dapat digunakan oleh dokter dan perawat pada klinik pribadi dokter, hanya dokter yang bisa melihat dan menambahkan data rekam medis perawat hanya bisa melihat saja, dokter dan perawat dapat mengelola data rekam medis pasien dengan praktis menggunakan rekam medis mobile dan daring[26].

Eka Mistiko Rini, dkk (2015) dengan judul PerancanganAplikasi Rekam Medis dan Sistem Antrian pada Praktek Dokter Umum (Studi kasus : Dr. Lintang Desi Aritanti Putri), menyimpulkan bahwa aplikasi rekam medis dan sistem antrian dibuat untuk membantu administrator dan pasien dalam proses pendaftaran dan dokumentasi rekam medis. Pada proses antrian pasien memiliki status yang ditampilkan pada aplikasi android, jika pasien tersebut sudah diperiksa oleh dokter maka statusnya akan berubah[18].

Dari beberapa penelitian diatas dapat ditarik kesimpulan bahwa sistem untuk rekam medis ini dapat menghemat tempat penyimpanan data pasien yang melakukan rekam medis dan memudahkan dalam pencarian nama pasien rekam medis, data rekam medis pasien yang dapat dikatakan rahasia tetap rahasia hanya admin atau dokter saja yang bisa menambahkan dan melihat data pasien, sistem ini lebih praktis digunakan dan sangat membantu petugas rekam medis. 


\section{METODOLOGI PENELITIAN}

\subsection{Metode Pengembangan Sistem}

Penelitian ini peneliti menggunakan metode pengembangan sistem dengan metode Waterfall. Air terjun (Waterfall) ini menyiratkan pendekatan yang sistematis dan berurutan pada perangkat lunak yang dimulai dari perencanaan (planning), pemodelan (modeling), konstruksi (construction), serta penyerahan perangkat lunak kepada pelanggan (deployment)[24].

Berikut merupakan langkah-langkah pengembangan Sistem Informasi Rekam Medis pada Dinas Kesehatan Kab. Musi Rawas Berbasis Web Mobile (Studi Kasus : Puskesmas Sungai Bunut, Puskesmas Pian Raya, Puskesmas Selangit) bisa dilihat pada gambar 3.

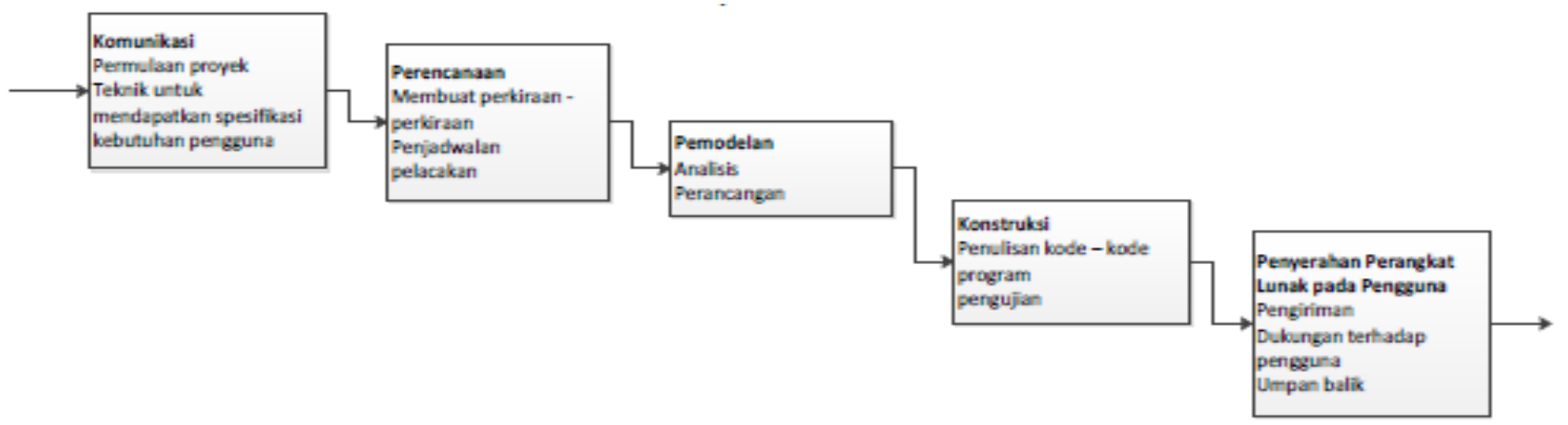

Gambar 1 Metode pengembangan sistem (waterfall)[24].

Adapun tahap-tahap yang dilakukan

pada pengembangan sistem dalam penelitian ini sebagai berikut:

1. Identifikasi Masalah

Dalam mendapatkan masalah penelitian, berpikir merupakan kegiatan pertama yang harus dilakukan untuk dapat memperoleh ide atau gagasan serta motivasi untuk bisa melakukan sebuah penelitian. Setelah itu, dilakukan sebuah survey mengenai subjek serta objek dari masalah yang terjadi, kemudian melakukan identifikasi masalah.

2. Tinjauan Pustaka

Studi pustaka merupakan metode yang berfokus pada pencarian penelitian yang berhubungan dan juga informasi dari berbagai jurnal ataupun buku untuk dapat mendukung proses penelitian dan penulisan.

3. Analisa Kebutuhan

Pada tahap analisa kebutuhan ini yang dilakukan adalah melakukan pengumpulan data-data yang ada pada
Puskesmas Sungai Bunut, Puskesmas Pian Raya dan Puskesmas Selangit. Data rekam medis yang dikumpulkan dijadikan acuan apa saja data yang akan disimpan pada layanan web yang akan dibuat.

4. Pengembangan Sistem

Pengembangan sistem yang dilakukan pada penelitian ini adalah menggunakan pengembangan sistem Waterfall.

a. Komunikasi

Komunikasi dengan pelanggan sebelum melakukan pekerjaan ini sangat penting untuk dipahami dan mencapai tujuan yang akan dicapai tercapai.

b. Perencanaan (Perkiraan, Penjadwalan, Pelacakan)

Diskusi menjelaskan tugas yang harus dilakukan, risiko apa yang terjadi, sumber daya yang dapat dihasilkan, dan penjadwalan masing-masing pekerjaan yang akan dilakukan serta pelacakan proses kerja sistem. 
c. Pemodelan (Analisis dan Desain)

Desain yang berfokus pada desain struktur data, arsitektur perangkat lunak, tampilan antarmuka, dan program.

d. Konstruksi (Kode dan Tes)

Menerjemahkan dalam bentuk desain ke dalam kode atau dari dari desain ke dalam kode atau bahasa yang dapat dibaca mesin tujuan menemukan kesalahan yang terjadi pada saat run time sehingga nantinya akan diperbaiki.

e. Penempatan (Pengiriman, Dukungan, Umpan Balik)

Tahapan implementasi perangkat lunak kepada pelanggan, pemeliharaan perangkat lunak, secara berkala, perangkat lnak perbaikan, evaluasi perangkat lunak, dan pengembangan perangkat lunak berdasakan umpan balik yang diberikan sehingga sistem dapat terus berjalan dan berkembang sesuai dengan fungsinya[27].

5. Pengujian Sistem

Dalam pengujian sistem pada penilitian ini menggunakan pengujian sistem black box testing.

6. Perancangan Sistem

Dalam peancangan sistem dilakukan dengan menggunkan UML (Unified Modeling Lenguage) dalam bentuk class diagram, use case diagram, activity diagram, sequence dagram.

\subsection{Analisa Kebutuhan dan Analisa Sistem}

1. Metode Analisa

Dalam analisa ini, peneliti mengumpulkan data-data yang diperlukan dalam penelitian ini, seperti peninjauan langsung ke Puskesmas Sungai Bunut,
Puskesmas Pian Raya, Puskesmas Selangit, wawancara dengan KUPT Puskesmas.

\section{Analisis Permasalahan}

Puskesmas Sungai Bunut, Puskesmas Pian Raya dan Puskesmas Selangit tidak memiliki media khusus untuk mempermudah dalam melakukan Rekam Medis terhadap pasien dilakukan dengan mendata secara manual data rekam medis pasien, pendataan pasien seperti ini mempersulit petugas rekam medis dalam pencarian kembali data pasien. Sebab belum adanya sistem khusus dalam sinkronisasi data rekam medis dalam tiap-tiap Puskesmas pada wilayah Dinas Kesehatan Kab. Musirawas dengan studi kasus : Puskesmas Sungai Bunut, Puskesmas Pian Raya, Puskesmas Selangit akibatnya ketika pasien datang ke puskesmas lain maka harus melakukan pendataan ulang.

a. Analisis Pemecahan Masalah

Membangun sebuah sistem yang dapat menjadi media khusus untuk pendataan rekam medis pasien dan bisa tersinkronisasi ke Puskesmas lainnya yang berada di wilayah Dinas Kesehatan Kab. Musirawas dengan studi kasus : Puskesmas Sungai Bunut, Puskesmas Pian Raya, Puskesmas Selangit. Dengan memanfaatkan Bahasa pemrograman $P H P$ untuk membangun sistem dan $M y S Q L$ akan digunakan sebagai media penyimpanan data pada sistem informasi tersebut.

b. Analisis Kebutuhan Sistem

Kebutuhan data sistem yang diolah dalam Sistem Informasi Rekam Medis pada Wilayah Dinas Kesehatan Kab. Musi Rawas (Studi Kasus : Puskesmas Sungai Bunut, Puskesmas Pian Raya, Puskesmas Selangit) disini peneliti membutuhkan data rekam medis dan data dokter dari Puskesmas tersebut dalam kelengkapan dan sebagai acuan 
apa saja data yang harus disimpan dalam layanan web.

\section{Analisa Sistem}

Dalam Sistem Informasi Rekam Medis pada Wilayah Dinas Kesehatan Kab. Musi Rawas Berbasis Web Mobile (Studi Kasus : Puskesmas Sungai Bunut, Puskesmas Pian Raya, Puskesmas Selangit), peneliti menggunakan alat bantu $U M L$ berupa use case diagram, activity diagram, class diagram dan sequence diagram, UML (Unified Modeling Lenguage) adalah salah satu standar bahasa yang banyak digunakan di dunia industri untuk mendefinisikan requiretment, membuat analisis dan desain, serta menggambarkan arsitektur dalam pemrogrman berorientasi objek. Selain itu peneliti juga mendesain antar muka berupa input dan output yang dapat menjadikan sistem sesuai yang diharapkan oleh peneliti.

\section{a. Diagram Use Case}

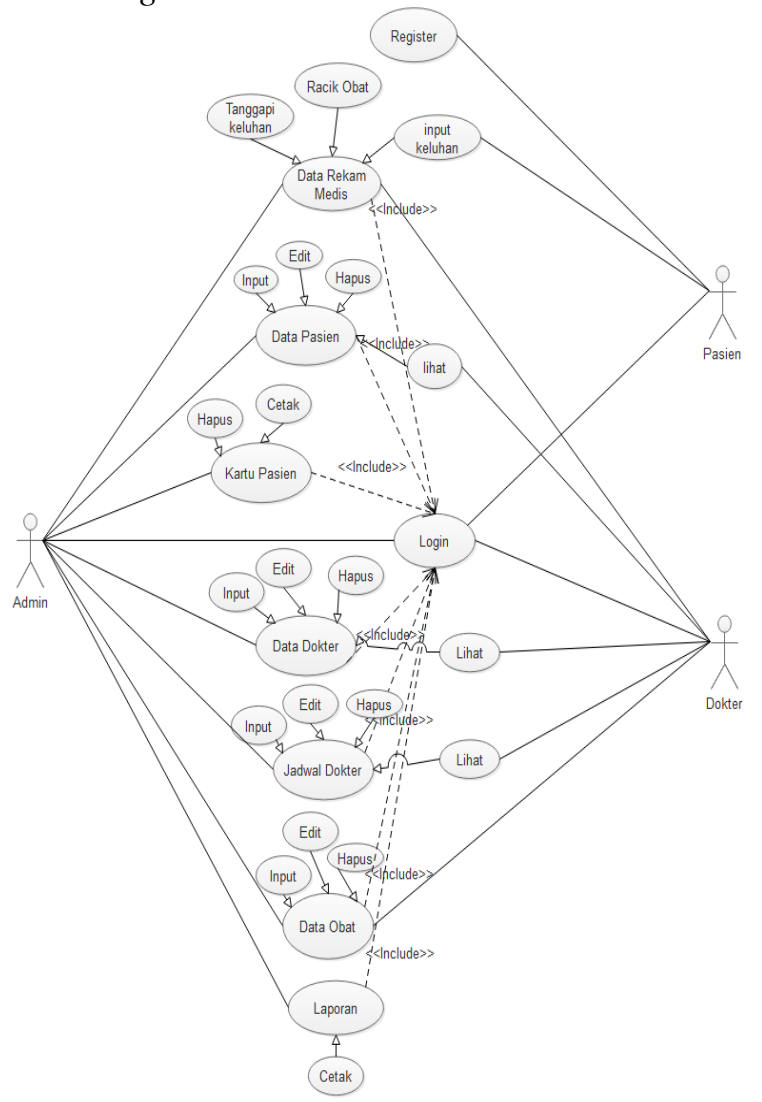

Gambar 2 Use Case Diagram b. Perancangan Class Diagram

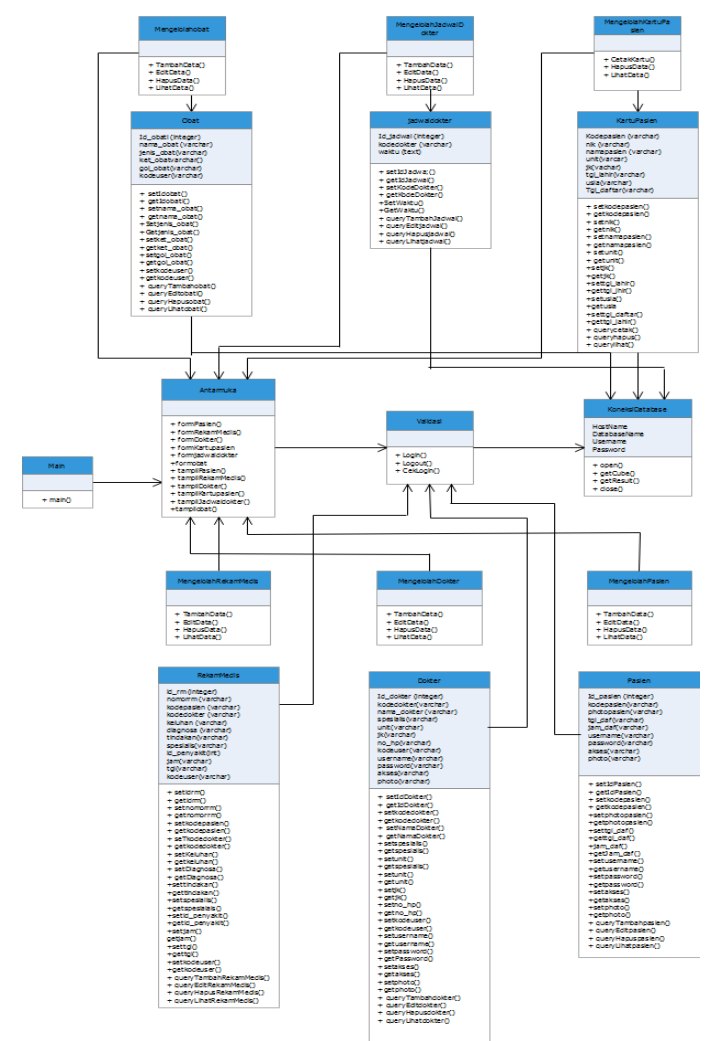

Gambar 3 Class Diagram

\section{HASIL DAN PEMBAHASAN}

\subsection{Hasil Penelitian}

Hasil dari penelitian selama kurang lebih enam bulan di Puskesmas Sungai Bunut, Puskesmas Pian Raya dan Puskesmas Selangit, maka hasil yang diperoleh adalah peneliti merancang sebuah sistem informasi rekam medis berbasis web mobile yang dapat diakses oleh semua perangkat. Sistem yang berjalan selama ini di tempat tersebut masih belum terkomputerisasi dengan baik dalam melakukan pemeriksaan rekam medis pasien, dalam hal ini sistem yang akan diterapkan adalah sistem informasi rekam medis yang berbasis web mobile untuk mempermudahkan pihak puskesmas yang terkait dalam melakukan pemeriksaan rekam medis terhadap pasien. 
JUTIM (Jurnal Teknik Informatika Musirawas)

Vol 05 No 02 Desember 2020
Taufik Rahman, Lukman Hakim Okta Maya Sari

\subsection{Pembahasan}

1. Tampilan Login

Halaman ini berfungsi untuk menampilkan halaman utama login sebelum masuk ke sistem rekam medis tiap aktor.

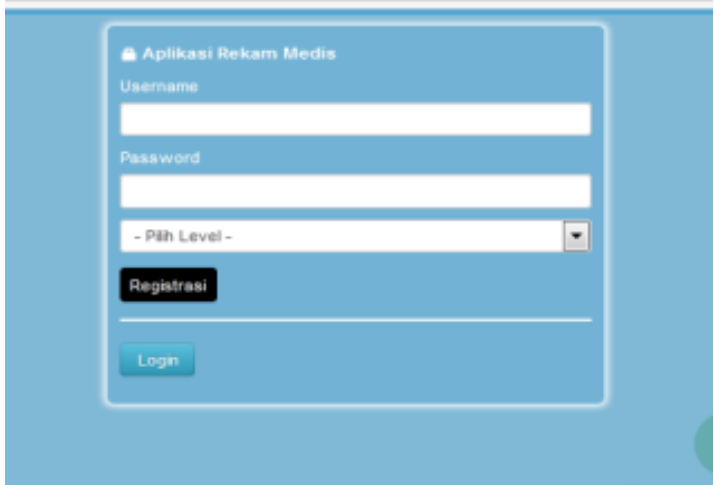

Gambar 4 Tampilan Login

2. Tampilan Register

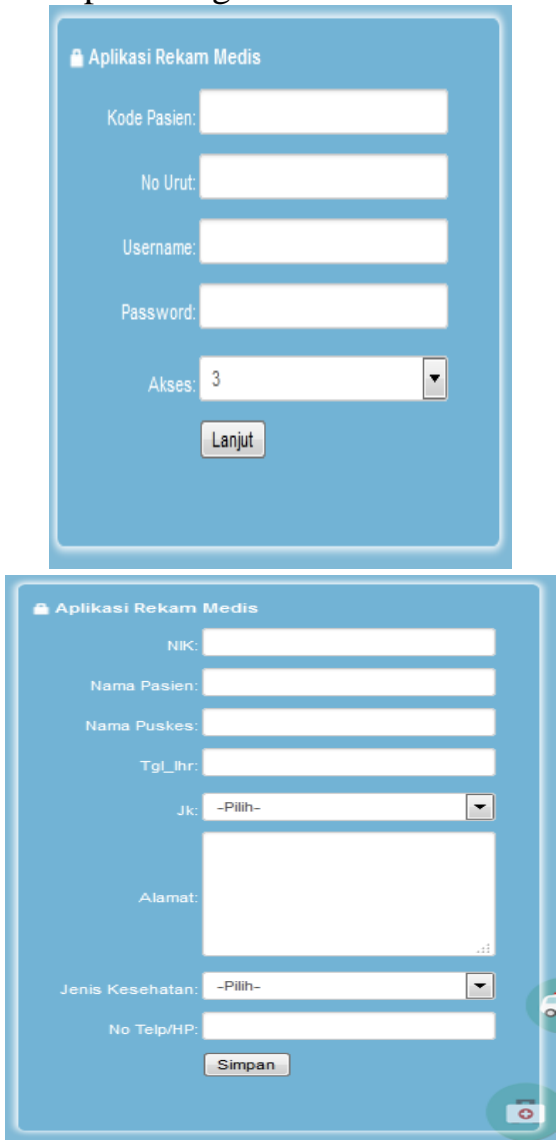

Gambar 5 Tampilan Register
3. Tampilan Home
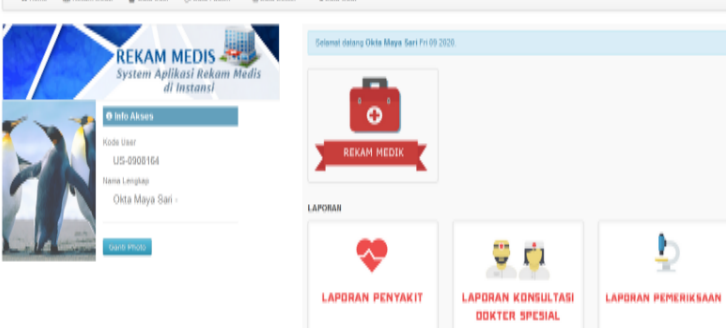

Gambar 6 Tampilan Home Admin
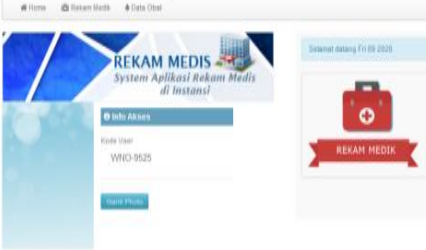

Gambar 7 Tampilan Home Pasien

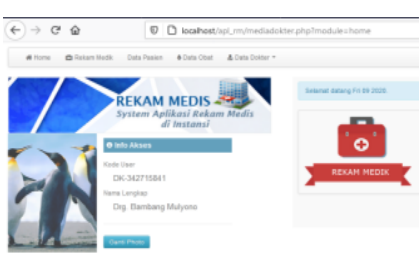

Gambar 8 Tampilan Home Dokter

4. Tampilan Data Pasien

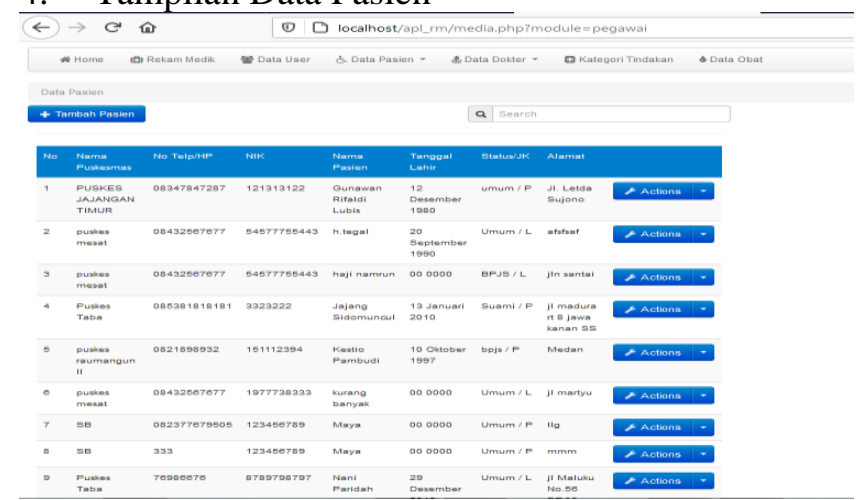

Gambar 9 Tampilan Data Pasien 
JUTIM (Jurnal Teknik Informatika Musirawas)

Vol 05 No 02 Desember 2020
Taufik Rahman, Lukman Hakim Okta Maya Sari
5. Tampilan Kartu Pasien

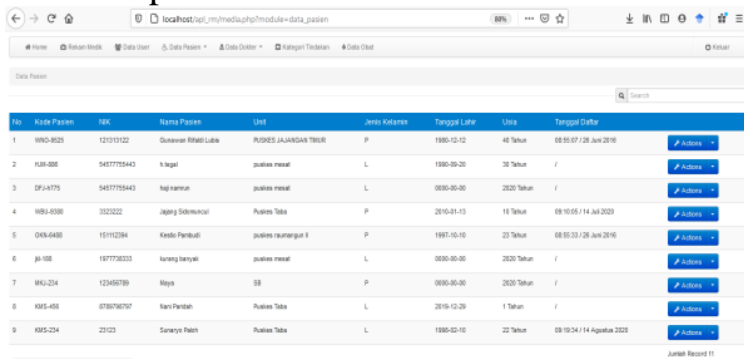

\section{Gambar 10 Tampilan Kartu Pasien}

6. Tampilan Data Dokter

\begin{tabular}{|c|c|c|c|c|c|c|c|}
\hline \multirow{2}{*}{$\begin{array}{l}t \rightarrow c \theta \\
=0.0=0\end{array}$} & \multicolumn{3}{|c|}{ 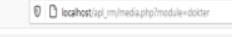 } & & m - - 可 & \multicolumn{2}{|c|}{ $\pm n \otimes \theta \rightarrow \| \# \equiv$} \\
\hline & nowe somat & sebae. & entres & a & & & ones \\
\hline \multicolumn{8}{|l|}{$\min$} \\
\hline tinener & & & & & & & \\
\hline 5 snomer & navoosen & sain & ut & munean & hane & noment & \\
\hline 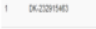 & atmingut & $=$ & $\log _{\text {the }}$ & ' & $"$ & mesem & 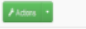 \\
\hline 2 seassos & aimsen & $m=m$ & $\sec _{0 \rightarrow \infty}$ & ' & 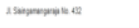 & massan & $m$ \\
\hline , $x<x=$ & 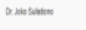 & $\infty$ & $m$ & ' & 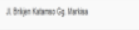 & 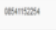 & 20 \\
\hline 1. xeassn & 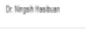 & $\Rightarrow$ & $n$ & & 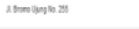 & maxames & $n=$ \\
\hline 3 solnawe & arang & $m$ & sentowe & i & 25800 & maxum & 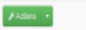 \\
\hline f wasn & sempanea & merenent & nate & t & abeat & шетет & $n$ \\
\hline i cxesengen & Do betervitum & $\infty$ & $\sin$ & i & $m$ & $m$ & $a$ \\
\hline
\end{tabular}

Gambar 11 Tampilan Data Dokter

7. Tampilan Jadwal Dokter

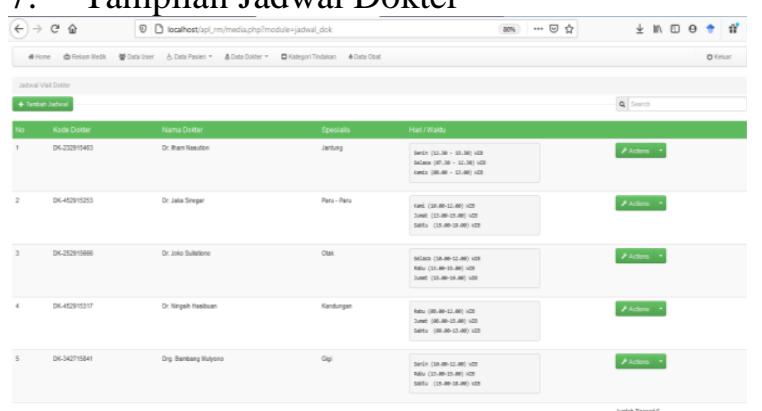

Gambar 12 Tampilan Jadwal Dokter

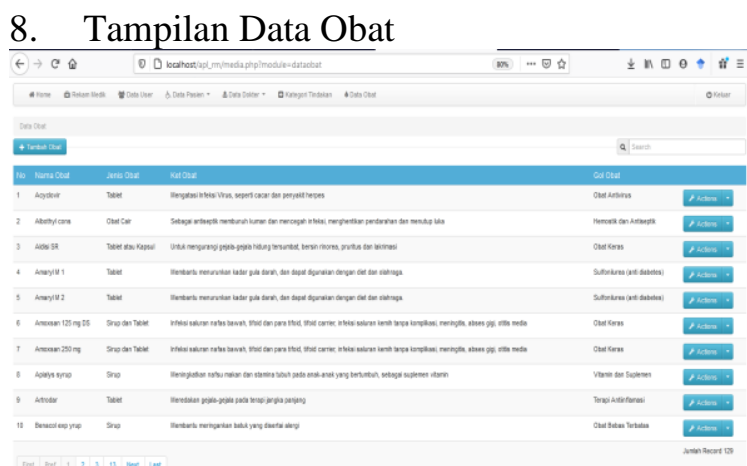

Gambar 13 Tampilan Data Obat
9. Tampilan Data Rekam Medis Pasien

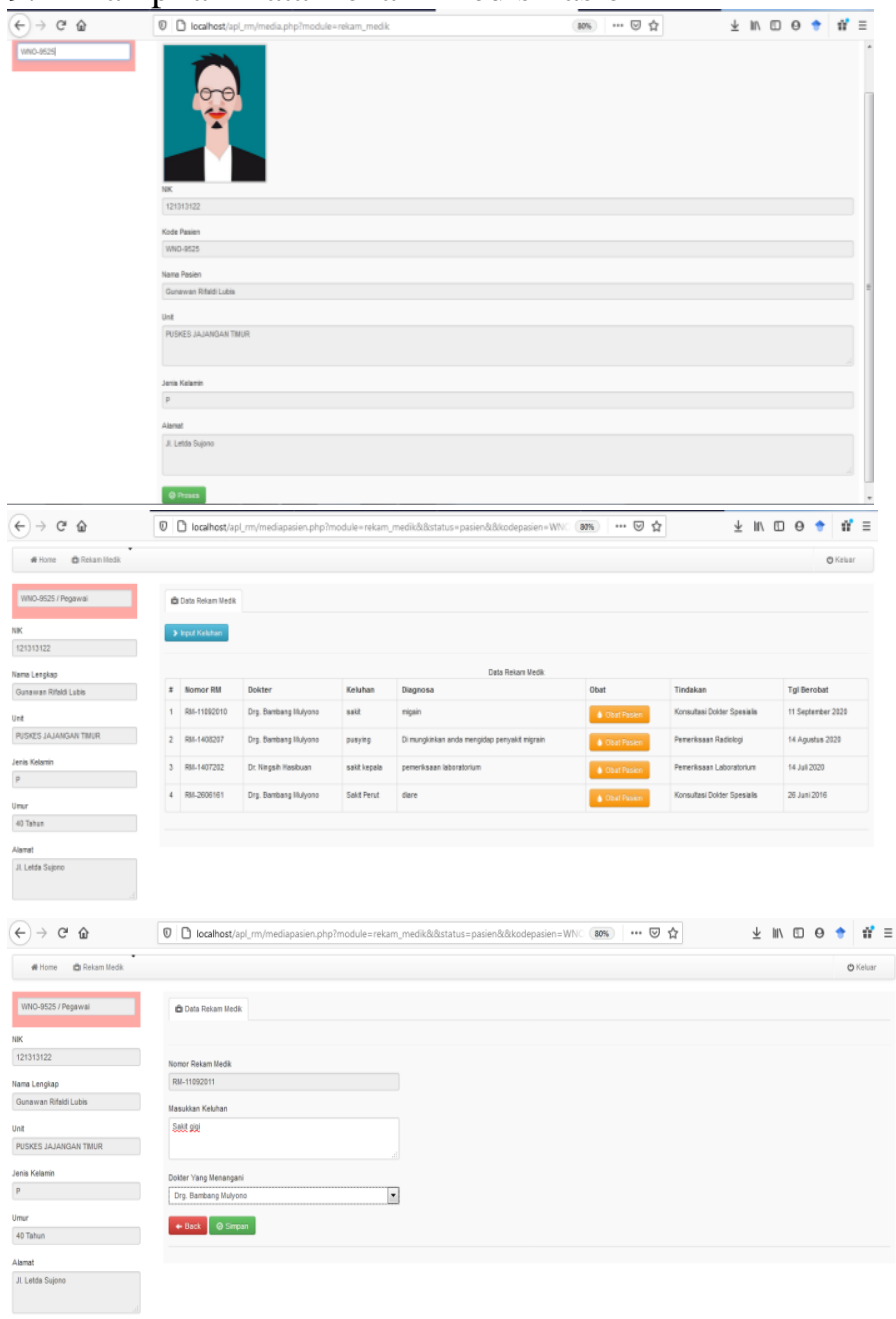

Gambar 14 Tampilan Data Rekam Medis Pasien

10. Halaman Data Rekam Medis Dokter

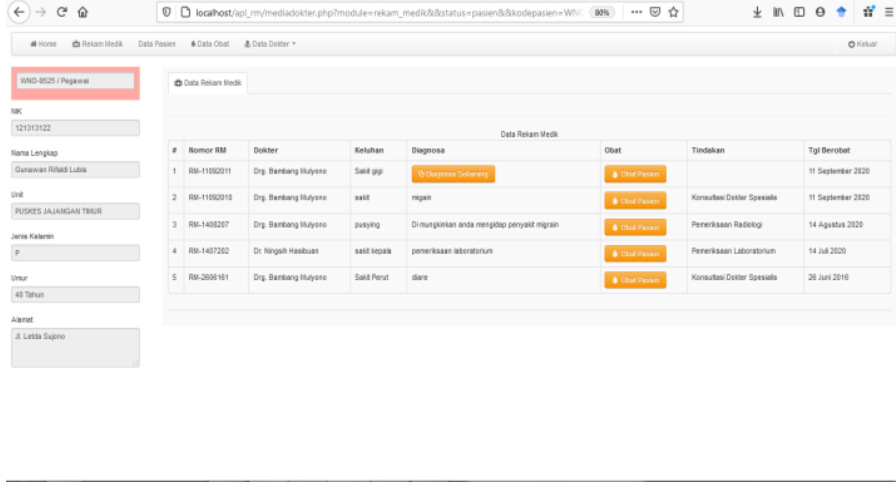




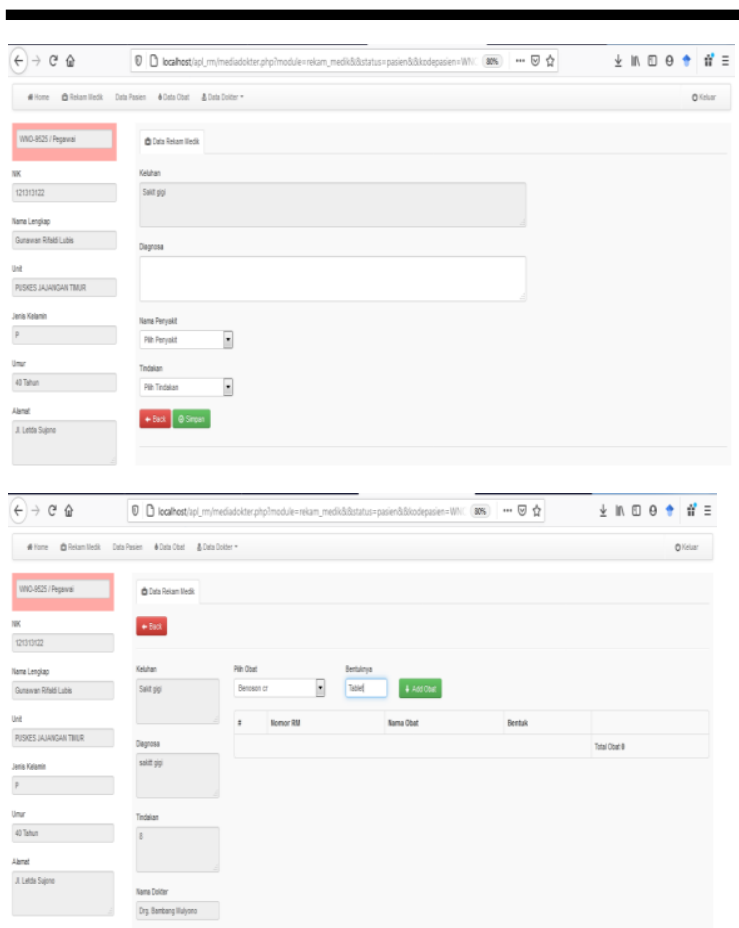

Gambar 15 Tampilan Data Rekam Medis Dokter

11. Tampilan Laporan

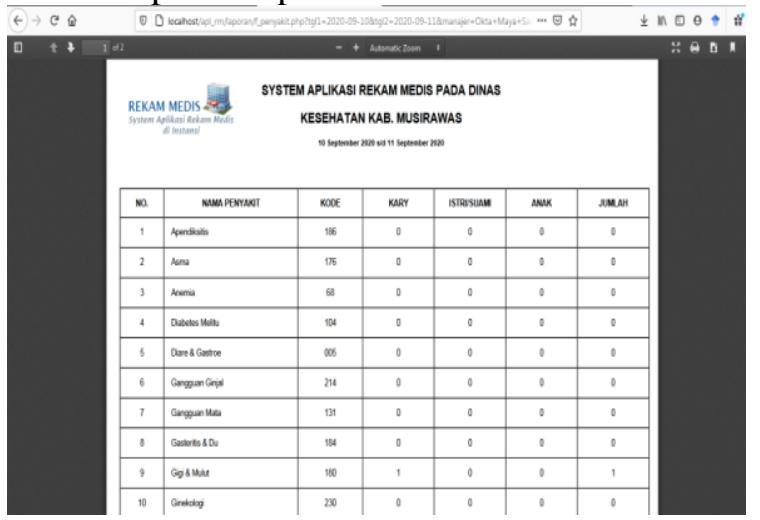

Gambar 16 Laporan Penyakit

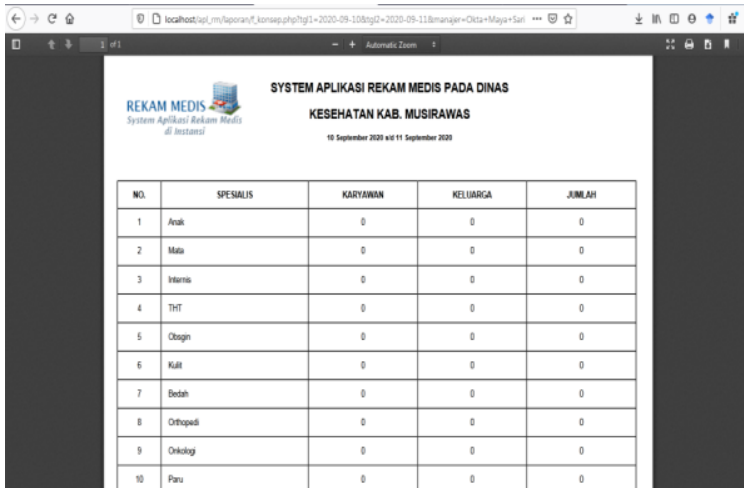

Gambar 17 Laporan Konsultasi Dokter Spesialis

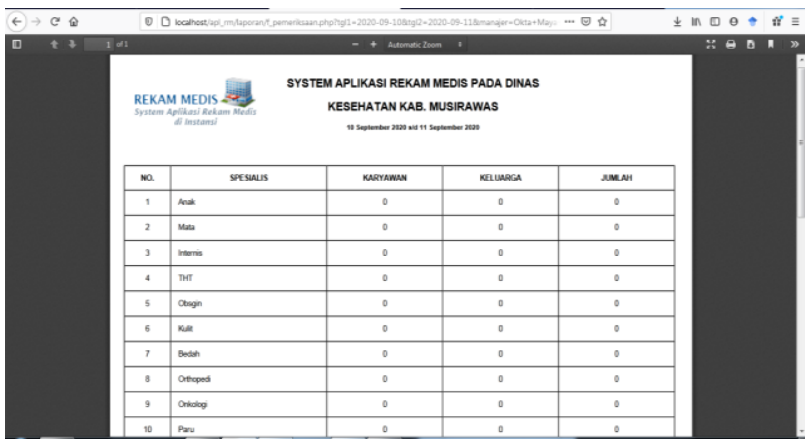

Gambar 18 Laporan Pemeriksaan

\subsection{Skenario Pengujian Sistem}

Pada tahap ini akan dilakukan pengujian sistem yang bertujuan untuk menemukan kesalahan kesalahan atau kekurangan kekurangan pada sistem yang diuji. Pengujian bermaksud untuk mengetahui sistem yang dibuat sudah memenuhi kriteria yang sesuai dengan tujuan perancangan sistem tersebut. Pengujian perangkat lunak ini menggunakan pengujian black box.

\section{Pengujian Login}

Berikut ini adalah hasil pegujian sistem menggunakan metode black box berdasarkan requitment pada rencana pengujian:

Tabel 1. Pengujian Form Login

\begin{tabular}{|c|c|c|c|}
\hline $\begin{array}{l}\text { Data } \\
\text { Masukan }\end{array}$ & $\begin{array}{l}\text { Yang } \\
\text { Diharapkan }\end{array}$ & $\begin{array}{l}\text { Pengamata } \\
\text { n }\end{array}$ & $\begin{array}{l}\text { Kesimpula } \\
\text { n }\end{array}$ \\
\hline $\begin{array}{l}\text { Username } \\
\text { dan } \\
\text { password } \\
: \quad \text { terisi } \\
\text { dengan } \\
\text { benar }\end{array}$ & $\begin{array}{l}\text { Akan } \\
\text { menampilk } \\
\text { an halaman } \\
\text { uatama }\end{array}$ & $\begin{array}{l}\text { Meampilk } \\
\text { an } \\
\text { halaman } \\
\text { utama }\end{array}$ & $\begin{array}{l}{[\sqrt{ }]} \\
\text { Diterima } \\
\text { [ ] Ditolak }\end{array}$ \\
\hline $\begin{array}{l}\text { Username } \\
\text { atau } \\
\text { password } \\
\text { salah }\end{array}$ & $\begin{array}{l}\text { Akan } \\
\text { menampilk } \\
\text { an pesan } \\
\text { "Login } \\
\text { Gagal, } \\
\text { silahkan } \\
\text { cek } \\
\text { username } \\
\text { dan } \\
\text { password" }\end{array}$ & $\begin{array}{l}\text { Akan } \\
\text { menampil } \\
\text { kan pesan } \\
\text { "Login } \\
\text { Gagal, } \\
\text { silahkan } \\
\text { cek } \\
\text { username } \\
\text { dan } \\
\text { password" }\end{array}$ & $\begin{array}{l}\sqrt{ } \\
\text { Diterima } \\
\text { [ ] Ditolak }\end{array}$ \\
\hline $\begin{array}{l}\text { Username } \\
\text { dan }\end{array}$ & $\begin{array}{l}\text { Akan } \\
\text { menampilk } \\
\text { an pesan }\end{array}$ & $\begin{array}{l}\text { Akan } \\
\text { menampil } \\
\text { kan pesan }\end{array}$ & $\begin{array}{l}{[\sqrt{ }]} \\
\text { Diterima } \\
\text { [ ] Ditolak }\end{array}$ \\
\hline
\end{tabular}


JUTIM (Jurnal Teknik Informatika Musirawas)

Vol 05 No 02 Desember 2020
Taufik Rahman, Lukman Hakim

Okta Maya Sari

\begin{tabular}{|l|l|l|l|}
\hline $\begin{array}{l}\text { password } \\
\text { kosong }\end{array}$ & $\begin{array}{l}\text { "Silahkan } \\
\text { Login } \\
\text { kembali" }\end{array}$ & $\begin{array}{l}\text { "Silahkan } \\
\text { Login } \\
\text { kembali" }\end{array}$ & \\
\hline
\end{tabular}

2. Pengujian Penginputan Data Pasien

Tabel 2. Pengujian Penginputan Data Pasien

\begin{tabular}{|c|c|c|c|}
\hline $\begin{array}{l}\text { Data } \\
\text { Masukan }\end{array}$ & $\begin{array}{l}\text { Yang } \\
\text { Diharapkan }\end{array}$ & $\begin{array}{l}\text { Pengamata } \\
\mathrm{n}\end{array}$ & $\begin{array}{l}\text { Kesimpul } \\
\text { an }\end{array}$ \\
\hline $\begin{array}{l}\text { Tombol } \\
\text { tambah } \\
\text { pasien }\end{array}$ & $\begin{array}{l}\text { No pasien } \\
\text { otomatis } \\
\text { akan } \\
\text { bertambah }\end{array}$ & $\begin{array}{l}\text { No pasien } \\
\text { bertambah } \\
\text { secara } \\
\text { otomatis }\end{array}$ & $\begin{array}{l}{[\sqrt{ }]} \\
\text { Diterima } \\
\text { [ ] Ditolak }\end{array}$ \\
\hline $\begin{array}{l}\text { Klik } \\
\text { "Cari “ }\end{array}$ & $\begin{array}{l}\text { Masukan } \\
\text { pencarian } \\
\text { berdasarka } \\
\mathrm{n} \text { nama } \\
\text { pasien, jika } \\
\text { ada maka } \\
\text { akan } \\
\text { muncul } \\
\text { data pasien } \\
\text { tersebut, } \\
\text { jika tidak } \\
\text { ada akan } \\
\text { menampilk } \\
\text { an pesan } \\
\text { "Data tidak } \\
\text { ditemukan } \\
\text { " }\end{array}$ & $\begin{array}{l}\text { Tombol } \\
\text { "Cari" } \\
\text { dapat } \\
\text { berfungsi } \\
\text { sesuai } \\
\text { yang } \\
\text { diharapkan }\end{array}$ & $\begin{array}{l}{[\sqrt{ }]} \\
\text { Diterima } \\
\text { [ ] Ditolak }\end{array}$ \\
\hline $\begin{array}{l}\text { Klik } \\
\text { "Edit" }\end{array}$ & $\begin{array}{l}\text { Data di edit } \\
\text { atau di } \\
\text { perbarui }\end{array}$ & $\begin{array}{l}\text { Tombol } \\
\text { "Edit" } \\
\text { dapat } \\
\text { berfungsi } \\
\text { sesuai } \\
\text { yang } \\
\text { diharapkan }\end{array}$ & $\begin{array}{l}{[\sqrt{ }]} \\
\text { Diterima } \\
\text { [ ] Ditolak }\end{array}$ \\
\hline $\begin{array}{l}\text { Klik } \\
\text { "Hapus } \\
\text { " }\end{array}$ & $\begin{array}{l}\text { Akan } \\
\text { menampilk } \\
\text { an pesan } \\
\text { "apakah } \\
\text { anda yakin, } \\
\text { ingin } \\
\text { menghapus } \\
\text { data } \\
\text { pasien?" } \\
\text { apabila } \\
\text { klik oke } \\
\text { maka data } \\
\text { pasien } \\
\text { akan } \\
\text { terhapus, } \\
\text { jika cancel } \\
\text { maka data } \\
\text { pasien }\end{array}$ & $\begin{array}{l}\text { Tombol } \\
\text { "Hapus" } \\
\text { dapat } \\
\text { berfungsi } \\
\text { sesuai } \\
\text { yang } \\
\text { diharapkan }\end{array}$ & $\begin{array}{l}{[\sqrt{ }]} \\
\text { Diterima } \\
\text { [ ] Ditolak }\end{array}$ \\
\hline
\end{tabular}

\begin{tabular}{|l|l|l|l|}
\hline & $\begin{array}{l}\text { tidak di } \\
\text { hapus }\end{array}$ & & \\
\hline
\end{tabular}

3. Pengujian Mencetak Kartu Pasien

Tabel 3. Pengujian Mencetak Kartu Pasien

\begin{tabular}{|c|c|c|c|}
\hline \begin{tabular}{l|} 
Data \\
Masukan
\end{tabular} & $\begin{array}{l}\text { Yang } \\
\text { Diharapkan }\end{array}$ & $\begin{array}{l}\text { Pengamata } \\
\text { n }\end{array}$ & $\begin{array}{l}\text { Kesimpul } \\
\text { an }\end{array}$ \\
\hline $\begin{array}{l}\text { Klik } \\
\text { "Cari "، }\end{array}$ & $\begin{array}{l}\text { Masukan } \\
\text { pencarian } \\
\text { berdasarka } \\
\mathrm{n} \text { nama } \\
\text { pasien, jika } \\
\text { ada maka } \\
\text { akan } \\
\text { muncul } \\
\text { data pasien } \\
\text { tersebut, } \\
\text { jika tidak } \\
\text { ada akan } \\
\text { menampilk } \\
\text { an pesan } \\
\text { "Data tidak } \\
\text { ditemukan } \\
\text { ” }\end{array}$ & $\begin{array}{l}\text { Tombol } \\
\text { "Cari" } \\
\text { dapat } \\
\text { berfungsi } \\
\text { sesuai } \\
\text { yang } \\
\text { diharapkan }\end{array}$ & $\begin{array}{l}{[\sqrt{ }]} \\
\text { Diterima } \\
{[\text { ] Ditolak }}\end{array}$ \\
\hline $\begin{array}{l}\text { Klik } \\
\text { "Cetak" }\end{array}$ & $\begin{array}{l}\text { Jika klik } \\
\text { cetak maka } \\
\text { akan } \\
\text { mencatak } \\
\text { kartu } \\
\text { pasien } \\
\text { sesuai } \\
\text { dengan } \\
\text { data pasien } \\
\text { yang di } \\
\text { inputkan }\end{array}$ & $\begin{array}{l}\text { Tombol } \\
\text { "Cetak" } \\
\text { dapat } \\
\text { berfungsi } \\
\text { sesuai } \\
\text { yang } \\
\text { diharapkan }\end{array}$ & $\begin{array}{l}{[\sqrt{ }]} \\
\text { Diterima } \\
{[\text { ] Ditolak }}\end{array}$ \\
\hline $\begin{array}{l}\text { Klik } \\
\text { "Hapus } \\
\text { " }\end{array}$ & $\begin{array}{l}\text { Akan } \\
\text { menampilk } \\
\text { an pesan } \\
\text { "apakah } \\
\text { anda yakin, } \\
\text { ingin } \\
\text { menghapus } \\
\text { data } \\
\text { pasien?" } \\
\text { apabila } \\
\text { klik oke } \\
\text { maka data } \\
\text { pasien } \\
\text { akan } \\
\text { terhapus, } \\
\text { jika cancel } \\
\text { maka data } \\
\text { pasien }\end{array}$ & $\begin{array}{l}\text { Tombol } \\
\text { "Hapus" } \\
\text { dapat } \\
\text { berfungsi } \\
\text { sesuai } \\
\text { yang } \\
\text { diharapkan }\end{array}$ & $\begin{array}{l}{[\sqrt{ }]} \\
\text { Diterima } \\
\text { [ ] Ditolak }\end{array}$ \\
\hline
\end{tabular}




\begin{tabular}{|l|l|l|l|}
\hline & $\begin{array}{l}\text { tidak di } \\
\text { hapus }\end{array}$ & & \\
\hline
\end{tabular}

4. Pengujian Penginputan Data Dokter

Tabel 4. Pengujian Penginputan Data Dokter

\begin{tabular}{|c|c|c|c|}
\hline \begin{tabular}{l|} 
Data \\
Masukan
\end{tabular} & $\begin{array}{l}\text { Yang } \\
\text { Diharapkan }\end{array}$ & $\begin{array}{l}\text { Pengamata } \\
\mathrm{n}\end{array}$ & $\begin{array}{l}\text { Kesimpul } \\
\text { an }\end{array}$ \\
\hline $\begin{array}{l}\text { Tombol } \\
\text { tambah } \\
\text { dokter }\end{array}$ & $\begin{array}{l}\text { No dokter } \\
\text { otomatis } \\
\text { akan } \\
\text { bertambah }\end{array}$ & $\begin{array}{l}\text { No dokter } \\
\text { bertambah } \\
\text { secara } \\
\text { otomatis }\end{array}$ & $\begin{array}{l}{[\sqrt{ }]} \\
\text { Diterima } \\
\text { [ ] Ditolak }\end{array}$ \\
\hline $\begin{array}{l}\text { Klik } \\
\text { "Cari “ }\end{array}$ & $\begin{array}{l}\text { Masukan } \\
\text { pencarian } \\
\text { berdasarka } \\
\text { n nama } \\
\text { atau kode } \\
\text { dokter, jika } \\
\text { ada maka } \\
\text { akan } \\
\text { muncul } \\
\text { data dokter } \\
\text { tersebut, } \\
\text { jika tidak } \\
\text { ada akan } \\
\text { menampilk } \\
\text { an pesan } \\
\text { "Data tidak } \\
\text { ditemukan } \\
\text { ” }\end{array}$ & $\begin{array}{l}\text { Tombol } \\
\text { "Cari" } \\
\text { dapat } \\
\text { berfungsi } \\
\text { sesuai } \\
\text { yang } \\
\text { diharapkan }\end{array}$ & $\begin{array}{l}{[\sqrt{ }]} \\
\text { Diterima } \\
\text { [ ] Ditolak }\end{array}$ \\
\hline $\begin{array}{l}\text { Klik } \\
\text { "Edit" }\end{array}$ & $\begin{array}{l}\text { Data di edit } \\
\text { atau di } \\
\text { perbarui }\end{array}$ & $\begin{array}{l}\text { Tombol } \\
\text { "Edit" } \\
\text { dapat } \\
\text { berfungsi } \\
\text { sesuai } \\
\text { yang } \\
\text { diharapkan }\end{array}$ & $\begin{array}{l}{[\sqrt{ }]} \\
\text { Diterima } \\
\text { [ ] Ditolak }\end{array}$ \\
\hline $\begin{array}{l}\text { Klik } \\
\text { "Hapus } \\
\text { " }\end{array}$ & $\begin{array}{l}\text { Akan } \\
\text { menampilk } \\
\text { an pesan } \\
\text { "apakah } \\
\text { anda yakin, } \\
\text { ingin } \\
\text { menghapus } \\
\text { data } \\
\text { dokter?" } \\
\text { apabila } \\
\text { klik oke } \\
\text { maka data } \\
\text { pasien } \\
\text { akan } \\
\text { terhapus, } \\
\text { jika cancel } \\
\text { maka data } \\
\text { pasien }\end{array}$ & $\begin{array}{l}\text { Tombol } \\
\text { "Hapus" } \\
\text { dapat } \\
\text { berfungsi } \\
\text { sesuai } \\
\text { yang } \\
\text { diharapkan }\end{array}$ & $\begin{array}{l}{[\sqrt{ }]} \\
\text { Diterima } \\
\text { [ ] Ditolak }\end{array}$ \\
\hline
\end{tabular}

\begin{tabular}{|l|l|l|l|}
\hline & $\begin{array}{l}\text { tidak di } \\
\text { hapus }\end{array}$ & & \\
\hline
\end{tabular}

5. Pengujian Penginputan Data Jawal Dokter

Tabel 5. Pengujian Penginputan Data Jadwal Dokter

\begin{tabular}{|c|c|c|c|}
\hline $\begin{array}{l}\text { Data } \\
\text { Masukan }\end{array}$ & $\begin{array}{l}\text { Yang } \\
\text { Diharapkan }\end{array}$ & $\begin{array}{l}\text { Pengamata } \\
\text { n }\end{array}$ & $\begin{array}{l}\text { Kesimpul } \\
\text { an }\end{array}$ \\
\hline $\begin{array}{l}\text { Tombol } \\
\text { tambah } \\
\text { jadwal }\end{array}$ & $\begin{array}{l}\text { No jadwal } \\
\text { dokter } \\
\text { otomatis } \\
\text { akan } \\
\text { bertambah }\end{array}$ & $\begin{array}{l}\text { No jadwal } \\
\text { dokter } \\
\text { bertambah } \\
\text { secara } \\
\text { otomatis }\end{array}$ & $\begin{array}{l}\sqrt{ }] \\
\text { Diterima } \\
\text { [ ] Ditolak }\end{array}$ \\
\hline $\begin{array}{l}\text { Klik } \\
\text { "Cari “ }\end{array}$ & $\begin{array}{l}\text { Masukan } \\
\text { pencarian } \\
\text { berdasarka } \\
\mathrm{n} \text { nama } \\
\text { atau kode } \\
\text { dokter, jika } \\
\text { ada maka } \\
\text { akan } \\
\text { muncul } \\
\text { data dokter } \\
\text { tersebut, } \\
\text { jika tidak } \\
\text { ada akan } \\
\text { menampilk } \\
\text { an pesan } \\
\text { "Data tidak } \\
\text { ditemukan } \\
\text { " }\end{array}$ & $\begin{array}{l}\text { Tombol } \\
\text { "Cari" } \\
\text { dapat } \\
\text { berfungsi } \\
\text { sesuai } \\
\text { yang } \\
\text { diharapkan }\end{array}$ & $\begin{array}{l}{[\sqrt{ }]} \\
\text { Diterima } \\
\text { [ ] Ditolak }\end{array}$ \\
\hline $\begin{array}{l}\text { Klik } \\
\text { "Edit" }\end{array}$ & $\begin{array}{l}\text { Data di edit } \\
\text { atau di } \\
\text { perbarui }\end{array}$ & $\begin{array}{l}\text { Tombol } \\
\text { "Edit" } \\
\text { dapat } \\
\text { berfungsi } \\
\text { sesuai } \\
\text { yang } \\
\text { diharapkan }\end{array}$ & $\begin{array}{l}{[\sqrt{ }]} \\
\text { Diterima } \\
\text { [ ] Ditolak }\end{array}$ \\
\hline $\begin{array}{l}\text { Klik } \\
\text { "Hapus } \\
\text { ” }\end{array}$ & $\begin{array}{l}\text { Akan } \\
\text { menampilk } \\
\text { an pesan } \\
\text { "apakah } \\
\text { anda yakin, } \\
\text { ingin } \\
\text { menghapus } \\
\text { data } \\
\text { dokter?" } \\
\text { apabila } \\
\text { klik oke } \\
\text { maka data } \\
\text { pasien } \\
\text { akan } \\
\text { terhapus, }\end{array}$ & $\begin{array}{l}\text { Tombol } \\
\text { "Hapus" } \\
\text { dapat } \\
\text { berfungsi } \\
\text { sesuai } \\
\text { yang } \\
\text { diharapkan }\end{array}$ & $\begin{array}{l}{[\sqrt{ }]} \\
\text { Diterima } \\
\text { [ ] Ditolak }\end{array}$ \\
\hline
\end{tabular}


JUTIM (Jurnal Teknik Informatika Musirawas)

Vol 05 No 02 Desember 2020
Taufik Rahman, Lukman Hakim Okta Maya Sari

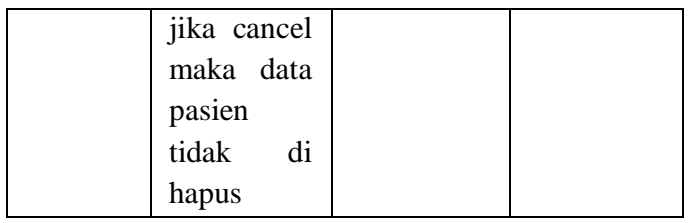

6. Pengujian Penginputan Data Obat

Tabel 6. Pengujian Penginputan Data Obat

\begin{tabular}{|c|c|c|c|}
\hline $\begin{array}{l}\text { Data } \\
\text { Masukan }\end{array}$ & $\begin{array}{l}\text { Yang } \\
\text { Diharapkan }\end{array}$ & $\begin{array}{l}\text { Pengamata } \\
\mathrm{n}\end{array}$ & $\begin{array}{l}\text { Kesimpul } \\
\text { an }\end{array}$ \\
\hline $\begin{array}{l}\text { Tombol } \\
\text { tambah } \\
\text { obat }\end{array}$ & $\begin{array}{l}\text { No obat } \\
\text { otomatis } \\
\text { akan } \\
\text { bertambah }\end{array}$ & $\begin{array}{l}\text { No obat } \\
\text { bertambah } \\
\text { secara } \\
\text { otomatis }\end{array}$ & $\begin{array}{l}{[\sqrt{ }]} \\
\text { Diterima } \\
\text { [ ] Ditolak }\end{array}$ \\
\hline $\begin{array}{l}\text { Klik } \\
\text { "Cari “ }\end{array}$ & $\begin{array}{l}\text { Masukan } \\
\text { pencarian } \\
\text { berdasarka } \\
\mathrm{n} \text { nama } \\
\text { obat, jika } \\
\text { ada maka } \\
\text { akan } \\
\text { muncul } \\
\text { data obat } \\
\text { tersebut, } \\
\text { jika tidak } \\
\text { ada akan } \\
\text { menampilk } \\
\text { an pesan } \\
\text { "Data tidak } \\
\text { ditemukan } \\
\text { " }\end{array}$ & $\begin{array}{l}\text { Tombol } \\
\text { "Cari" } \\
\text { dapat } \\
\text { berfungsi } \\
\text { sesuai } \\
\text { yang } \\
\text { diharapkan }\end{array}$ & $\begin{array}{l}{[\sqrt{ }]} \\
\text { Diterima } \\
\text { [ ] Ditolak }\end{array}$ \\
\hline $\begin{array}{l}\text { Klik } \\
\text { "Edit" }\end{array}$ & $\begin{array}{l}\text { Data di edit } \\
\text { atau di } \\
\text { perbarui }\end{array}$ & $\begin{array}{l}\text { Tombol } \\
\text { "Edit" } \\
\text { dapat } \\
\text { berfungsi } \\
\text { sesuai } \\
\text { yang } \\
\text { diharapkan }\end{array}$ & $\begin{array}{l}{[\sqrt{ }]} \\
\text { Diterima } \\
\text { [ ] Ditolak }\end{array}$ \\
\hline $\begin{array}{l}\text { Klik } \\
\text { “Hapus } \\
\text { ” }\end{array}$ & $\begin{array}{l}\text { Akan } \\
\text { menampilk } \\
\text { an pesan } \\
\text { "apakah } \\
\text { anda yakin, } \\
\text { ingin } \\
\text { menghapus } \\
\text { data obat?" } \\
\text { apabila } \\
\text { klik oke } \\
\text { maka data } \\
\text { pasien } \\
\text { akan } \\
\text { terhapus, } \\
\text { jika cancel } \\
\text { maka data }\end{array}$ & $\begin{array}{l}\text { Tombol } \\
\text { "Hapus" } \\
\text { dapat } \\
\text { berfungsi } \\
\text { sesuai } \\
\text { yang } \\
\text { diharapkan }\end{array}$ & $\begin{array}{l}{[\sqrt{ }]} \\
\text { Diterima } \\
\text { [ ] Ditolak }\end{array}$ \\
\hline
\end{tabular}

\begin{tabular}{|l|l|l|l|}
\hline & $\begin{array}{l}\text { pasien } \\
\text { tidak di } \\
\text { hapus }\end{array}$ & & \\
\hline
\end{tabular}

7. Penginputan Rekam Medis

Tabel 7. Penginputan Rekam Medis

\begin{tabular}{|c|c|c|c|}
\hline $\begin{array}{l}\text { Data } \\
\text { Masukan }\end{array}$ & $\begin{array}{l}\text { Yang } \\
\text { Diharapkan }\end{array}$ & $\begin{array}{l}\text { Pengamata } \\
\text { n }\end{array}$ & $\begin{array}{l}\text { Kesimpul } \\
\text { an }\end{array}$ \\
\hline $\begin{array}{l}\text { Kode } \\
\text { Pasien }\end{array}$ & $\begin{array}{ll}\text { Kode } & \\
\text { pasien } & \\
\text { dapat } & \text { di } \\
\text { proses } & \\
\end{array}$ & $\begin{array}{l}\text { Kode } \\
\text { pasien bisa } \\
\text { di proses }\end{array}$ & $\begin{array}{l}{[\sqrt{ }]} \\
\text { Diterima } \\
\text { [ ] Ditolak }\end{array}$ \\
\hline $\begin{array}{l}\text { Klik } \\
\text { "Input } \\
\text { Keluhan } \\
\text { “ }\end{array}$ & $\begin{array}{l}\text { Akan } \\
\text { menampilk } \\
\text { an form } \\
\text { keluhan } \\
\text { yang dapat } \\
\text { di isi oleh } \\
\text { pasien }\end{array}$ & $\begin{array}{l}\text { Input } \\
\text { keluhan } \\
\text { dapat } \\
\text { berfungsi } \\
\text { sesuai } \\
\text { yang } \\
\text { diharapkan }\end{array}$ & $\begin{array}{l}{[\sqrt{ }]} \\
\text { Diterima } \\
\text { [ ] Ditolak }\end{array}$ \\
\hline $\begin{array}{l}\text { Klik } \\
\text { "Simpan } \\
\text { ", }\end{array}$ & $\begin{array}{l}\text { Jika di } \\
\text { Klik maka } \\
\text { keluhan } \\
\text { yang sudah } \\
\text { di isi akan } \\
\text { masuk ke } \\
\text { sistem } \\
\text { dokter } \\
\text { yang sudah } \\
\text { di pilih }\end{array}$ & $\begin{array}{l}\text { Tombol } \\
\text { "Simpan" } \\
\text { dapat } \\
\text { berfungsi } \\
\text { sesuai } \\
\text { yang } \\
\text { diharapkan }\end{array}$ & $\begin{array}{l}{[\sqrt{ }]} \\
\text { Diterima } \\
\text { [ ] Ditolak }\end{array}$ \\
\hline $\begin{array}{l}\text { Klik } \\
\text { "Back" }\end{array}$ & $\begin{array}{l}\text { Jika di } \\
\text { Klik maka } \\
\text { akan } \\
\text { kembali ke } \\
\text { halaman } \\
\text { data rekam } \\
\text { medis }\end{array}$ & $\begin{array}{l}\text { Tombol } \\
\text { "Back" } \\
\text { dapat } \\
\text { berfungsi } \\
\text { sesuai } \\
\text { yang } \\
\text { diharapkan }\end{array}$ & $\begin{array}{l}{[\sqrt{ }]} \\
\text { Diterima } \\
\text { [ ] Ditolak }\end{array}$ \\
\hline $\begin{array}{l}\text { Klik } \\
\text { "Diagno } \\
\text { sa } \\
\text { Sekaran } \\
\text { g“" }\end{array}$ & $\begin{array}{l}\text { Akan } \\
\text { menampilk } \\
\text { an form } \\
\text { diagnosa } \\
\text { yang dapat } \\
\text { di isi oleh } \\
\text { dokter }\end{array}$ & $\begin{array}{l}\text { Tombol } \\
\text { diagnosa } \\
\text { sekarang } \\
\text { dapat } \\
\text { berfungsi } \\
\text { sesuai } \\
\text { yang } \\
\text { diharapkan }\end{array}$ & $\begin{array}{l}{[\sqrt{ }]} \\
\text { Diterima } \\
\text { [ ] Ditolak }\end{array}$ \\
\hline $\begin{array}{l}\text { Klik } \\
\text { "Obat } \\
\text { Pasien" }\end{array}$ & $\begin{array}{l}\text { Akan } \\
\text { menampilk } \\
\text { an data } \\
\text { obat yang } \\
\text { akan } \\
\text { diberikan } \\
\text { kepada } \\
\text { pasien }\end{array}$ & $\begin{array}{l}\text { Tombol } \\
\text { obat } \\
\text { pasien } \\
\text { dapat } \\
\text { berfungsi } \\
\text { sesuai } \\
\text { yang } \\
\text { diharapkan }\end{array}$ & $\begin{array}{l}{[\sqrt{ }]} \\
\text { Diterima } \\
\text { [ ] Ditolak }\end{array}$ \\
\hline
\end{tabular}




\section{KESIMPULAN}

Dibuatnya sistem rekam medis ini, peneliti dapat membuat beberapa kesimpulan diantaranya:

1. Pelayanan rekam medis berbasis web mobile ini dapat memudahkan masyarakat dalam melakukan pendaftaran secara online, melakukan pemeriksaan secara mudah dan cepat, serta dapat melihat catatan medis kapan pun dan dimana saja tanpa perlu datang ke puskesmas.

2. Penggunaan sistem informasi rekam medis ini dapat melakukan pengolahan data rekam medis yang dilakukan dengan penginputan data, mengcopy dan mencetak data laporan rekam medis, dimana semua data yang diperlukan disimpan dalam satu database.

3. Sistem informasi rekam medis ini dapat mengatasi masalah penambahan data yang identik dengan kertas yang menumpuk dan memenuhi ruangan.

4. Penggunaan sistem yang sudah terkomputerisasi dengan baik dapat mengurangi duplikat atau kesalahan dalam pencatatan.

5. Dapat diarsipkan dalam bentuk soft file sehingga mengurangi resiko hilang atau rusaknya data. Pengarsipan dalam bentuk soft file juga mempermudah penggunaan dalam mencari data.

\section{SARAN}

Dalam melakukan penelitian ini, peneliti menyadari masih banyak kekurangan, akan tetapi setelah melakukan pengujian secara keseluruhan terdapat beberapa saran yang peneliti simpulkan baik dari peneliti maupun saran sebagai berikut :

1. Sistem tidak hanya menangani rekam medis, sebaiknya dilengkapi dengan cara penanganannya, seperti memberikan rawat inap dan rawat jalan.
2. Perlu adanya evaluasi sistem secara berkala untuk mengimbangi perubahanperubahan yang terjadi, sehingga masalah yang terjadi bisa teratasi.

\section{DAFTAR PUSTAKA}

[1] L. S. Helling, E. Wahyudi, and H. Hasanudin, "Siremis: Sistem Informasi Rekam Medis Puskesmas Kecamatan Matraman Jakarta," INTENSIF J. Ilm. Penelit. dan Penerapan Teknol. Sist. Inf., vol. 3, no. 2, p. 116, 2019.

[2] S. Setiatin and S. R. Agustin, "Perancangan Sistem Informasi Pelayanan Rekam Medis Di Puskesmas Arcamanik Kota Bandung," J. Manaj. Inf. Kesehat. Indones., vol. 7, no. 1, p. 33, 2019.

[3] K. Arif and A. Ambarita, "Sistem Pengolahan Data Rekam Medis Berbasis Web Pada Puskesmas Perawatan Jambula Kota Ternate," IJIS - Indones. J. Inf. Syst., vol. 1, no. 2, 2016.

[4] A. Prasetyo and M. S. Azis, "Perancangan Sistem Informasi Rekam Medis Pada Puskesmas Jomin Berbasis Web," J. Interkom Vol. 13 No. 2, vol. 13, no. 2, pp. 3138, 2018.

[5] A. Ramadhanu, R. H. Arsyah, H. Syahputra, and V. Okta, "Sistem Informasi Pelayanan Kesehatan dan Rekam Medis pada Klinik Dirmiati Palapa Menggunakan Visual Basic dan MySQL," vol. 3, no. 1, pp. 4956, 2019.

[6] E. Tekat et al., "Sistem Informasi Pengendalian Persediaan Stok Lensa Berbasis Web pada Optik Trio Jaya Cabang Tangerang," vol. 9, no. 2, 2019.

[7] S. Informasi and M. B. Data, "Jurnal simada," vol. 2, no. 1, 2019.

[8] J. N. Informatika, "Puskesmas merupakan penyelenggara pelayanan kesehatan yang paling dekat dengan masyarakat menunjukkan lebih dari $40 \%$ penduduk Indonesia yang 
memanfaatkan pelayanan kesehatan di Hal tersebut memperlihatkan bahwa Puskesmas sebagai penyelenggara layanan kes," vol. 13, pp. 19-23, 2019.

[9] A. Astutik and S. Endra, "Rancang Bangun Aplikasi Rekam Medis Pasien Berbasis Web Pada Klinik TS Beauty Center Bojonegoro," Jsika, vol. 7, no. 1, pp. 1-7, 2018.

[10] M. Iqbal, A. Sudiarjo, and Hendrawansyah, "Perancangan Sistem Informasi Rekam Medis Studi Kasus Klinik Suma Medika," vol. 8, no. 2, 2018.

[11] N. A. Anwar, B. Priyambadha, and A. Arwan, "Pengembangan Aplikasi Web Rekam Medis Studi Kasus RSIA . Prof . Prof. Dr. H. M. Farid Makassar," J. Pengemb. Teknol. Inf. dan Ilmu Komput. Univ. Brawijaya, vol. 3, no. 1, pp. 267-273, 2019.

[12] R. S. Kusumadiarti et al., "LABORATORIUM DI PUSKESMAS," vol. 5, pp. 48-54, 2019.

[13] E. Pratiwi and M. Muslihudin, "Implementasi E-Goverment Sebagai Upaya Peningkatan Potensi Desa Di Desa Bumirejo Menggunakan Web Mobile," Technol. Accept. Model, vol. 9, no. 1, pp. 22-29, 2018.

[14] R. Sistem, "JURNAL RESTI Implementasi E - Modul pada Program Studi Manajemen Informatika," vol. 2, no. 2, pp. 492497, 2018.

[15] N. I. Fadlilah and F. B. Nabilah, "Sistem Informasi Sedekah Nasi " Senasbuto 'Purwokerto Berbasis Website," vol. 9, no. 1, pp. 26-33, 2020.

[16] E. Budiman, R. Hasudungan, and A. Khoiri, "Online Game " Pics and Words ' Sebagai Media Edukasi Bahasa Inggris Berbasis Html," vol. 2, no. 1, pp. 1-6, 2017.

[17] S. Lestanti and A. D. Susana, "Jurnal Antivirus, Vol. 10," vol. 10, no. 2, pp. 69-77, 2016.

[18] E. M. Rini, D. Suwardiyanto, and P. Rahayu, "Sistem Informasi
Perancangan Aplikasi Rekam Medis Dan Sistem Antrian Pada Praktek Dokter Umum ( Studi Kasus : Dr . Lintang Desi Aritanti Putri )," pp. 205-210, 2015.

[19] A. Suprianto and A. A. F. Matsea, "Rancang Bangun Aplikasi Pendaftaran Pasien Online Dan Pemeriksaan Dokter Di Klinik Pengobatan Berbasis Web," $J$. Rekayasa Inf., vol. 7, no. 1, pp. 4858, 2018.

[20] A. B. Putra and S. Nita, "Perancangan dan Pembangunan Sistem Informasi E-Learning Berbasis Web ( Studi Kasus Pada Madrasah Aliyah Kare Madiun )," Semin. Nas. Teknol. Inf. dan Komun. 2019, vol. 1, no. 1, pp. 81-85, 2019.

[21] Fatimah and Samsudin, "Perancangan Sistem Informasi EJurnal Pada Prodi Sistem," vol. 1, pp. 33-49, 2019.

[22] S. Iisnaini and B. Riski, "Aplikasi EVote Pemilihan Presiden Badan Eksekutif Mahasiswa ( Bem ) Amik Dian Cipta Cendikia Bandar Lampung Berbasis Web," vol. 2, pp. 27-36, 2019.

[23] N. D. Pratiwi and A. A. Mudayana, "Abstrak Abstrac," vol. 14, no. 3, 2019.

[24] L. Setiyani, "[ Software Engineering ] Lila Setiyani, S . T , M . Kom," no. May, 2019.

[25] R. A.S and M. Shalahuddin, REKAYASA PERANGKAT LUNAK, Revisi. Bandung: BI-Obses, 2018.

[26] I. Putra and R. Dawood, "Rancang Bangun Layanan Web (Web Service) Untuk Aplikasi Rekam Medis Praktik Pribadi Dokter," Karya Ilm. Mhs. Tek. Elektro, vol. 2, no. 1, pp. 9-15, 2017.

[27] F. J. Tampubolon, "ANALYSIS AND DESIGN OF ORDERING SYSTEM OF BUILDING MATERIAL AND EQUIPMENT CASE STUDY: SERBA-JAYA BUILDING SHOP," vol. 5, no. 4, pp. 160-167, 2018. 